\title{
Taxonomic revision of doubtful Brazilian freshwater shrimp species of genus Macrobrachium (Decapoda, Palaemonidae)
}

\author{
Leonardo G. Pileggi \& Fernando L. Mantelatto
}

Laboratório de Bioecologia e Sistemática de Crustáceos, Departamento de Biologia, Faculdade de Filosofia, Ciências e Letras de Ribeirão Preto (FFCLRP), Universidade de São Paulo (USP), Av. Bandeirantes 3900, 14040-901, Ribeirão Preto, SP, Brazil. (lpileggi@gmail.com; flmantel@usp.br)

\begin{abstract}
The freshwater prawns of the genus Macrobrachium Spence Bate, 1868 are widely distributed in rivers of tropical and subtropical regions and represent an interesting group with controversial taxonomy. The morphological characters traditionally used to separate species have shown a high intraspecific variation. Doubts about the status of M. birai Lobão, Melo \& Fernandes, 1986, M. holthuisi Genofre \& Lobão, 1978 and M. petronioi Melo, Lobão \& Fernandes, 1986 have been arisen due to the high resemblance of the former two species with M. olfersi (Wiegmann, 1836), and the latter one with M. potiuna (Müller, 1880). Therefore, we performed a detailed morphological analysis of these species, including new characters not usually used in the species recognition. The present results here with molecular data lead us to conclude that $M$. birai and $M$. holthuisi are junior synonyms of M. olfersi, and M. petronioi is a junior synonym of M. potiuna. Considering these synonymies, 17 valid species are now reported for the Brazilian territory.
\end{abstract}

KEYWORDS. Caridean shrimps; Crustacea; freshwater prawns; Neotropical region; Synonymy.

RESUMO. Revisão taxonômica das espécies brasileiras duvidosas de camarões de água doce do gênero Macrobrachium (Decapoda, Palaemonidae). Os camarões de água doce do gênero Macrobrachium Spence Bate, 1868 encontram-se amplamente distribuídos em rios de regiões tropicais e subtropicais e representam um grupo com taxonomia controversa. Os caracteres morfológicos comumente utilizados para separação de espécies apresentam uma grande variação intraespecífica. Dúvidas sobre o status taxonômico de $M$. birai Lobão, Melo \& Fernandes, 1986, M. holthuisi Genofre \& Lobão, 1978 e M. petronioi Melo, Lobão \& Fernandes, 1986 foram levantadas devido à alta similaridade morfológica das primeiras com relação à $M$. olfersi (Wiegmann, 1836) e da última com relação à M. potiuna (Müller, 1880). Assim, foi realizada uma análise morfológica detalhada de tais espécies, incluindo novos caracteres comumente não utilizados na identificação dos táxons. A partir dos resultados obtidos, juntamente com dados moleculares, concluímos que M. birai e M. holthuisi são sinônimos-júnior de M. olfersi, e M. petronioi é sinônimo-júnior de $M$. potiuna. Portanto, considerando-se tais sinonímias, são reportadas 17 espécies válidas para o território brasileiro.

PALAVRAS-CHAVE. Camarões carídeos; camarões de água doce; Crustacea; Região Neotropical; sinonímia.

Palaemonidae encompasses about 981 species (Fransen \& De Grave, 2009; De Grave \& Fransen, 2011) of which Macrobrachium Spence Bate, 1868 is one of the most relevant members regarding species richness. This genus includes approximately 240 species that are important components of freshwater and estuarine ecosystems distributed worldwide in tropical and subtropical waters and that presents the greatest diversity in the Indo-Pacific region (Wowor et al., 2009; De Grave \& Fransen, 2011). More than 55 species are found in the Americas, of which 20 have been reported from Brazil (Holthuis, 1952; Pereira, 1986, 1993; BowLEs et al., 2000; JAYACHANDRAN, 2001; Melo, 2003; Almaraz \& Martínez, 2008; Mantelatto et al., 2008).

The genus presents a difficult taxonomy due to strong interspecific conservatism and considerable intraspecific variation (Holthuis, 1950, 1952). Another factor of considerable importance that can contribute to the possible taxonomic errors refers to the influence of social dominance with implications in the male morphology, leading to the recognition of distinct hierarchical morphotypes (KURIS et al., 1987; MoraesRiodades \& Valenti, 2004; Wortham \& Van MauriK, 2012). Thus, the problem of distinguishing correctly fully developed males in the description of new species is clear and it is what may possibly have occurred in some Brazilian species descriptions. For these species, doubts about the taxonomic validity have been arisen from observations in the literature and during studies of specimens collected and deposited in museum collections. During the development of a comprehensive revision of the genus Macrobrachium from Brazil, including the analysis of type series and fresh material from the type localities, some of these dubious species with great morphological similarities came up: Macrobrachium birai Lobão, Melo \& Fernandes, 1986 and M. holthuisi Genofre \& Lobão, 1978 with M. olfersi (Wiegmann, 1836), and M. petronioi Melo, Lobão \& Fernandes, 1986 with M. potiuna (Müller, 1880). The morphological characters used to distinguish these species are quite similar, especially regarding the proportions of articles on the thoracic appendages (GenOFRe \& Lobão, 1978; LoB̃̃o et al., 1986; Melo et al., 1988).

According with the inconsistencies detected during previous morphologically investigations, we performed a taxonomic revision including new characters. This contribution is part of a long-term effort on the taxonomy and phylogeny of the American palaemonid freshwater species.

\section{MATERIAL AND METHODS}

The most part of the specimens were analyzed during our visit in the following crustacean collections: Museu de Zoologia, Universidade de São Paulo, São Paulo, 
Brazil (MZUSP) where the type material of $M$. birai, $M$. holthuisi and M. petronioi are deposited; Universidade Federal do Rio Grande do Sul, Porto Alegre, Brazil (UFRGS); Universidade Estadual de Santa Cruz, Ilhéus, Brazil (UESC); Instituto Nacional de Pesquisas da Amazônia, Manaus, Brazil (INPA); Naturalis Biodiversity Center Leiden, Netherlands (RMNH) where part of the type material of $M$. holthuisi are deposited; Museum für Naturkunde, Berlin, Germany (MNB) where the type material of $M$. olfersi are deposited. Some materials were obtained by donation or loan from the respective collections. Newly specimens were collected in rivers and estuaries in Brazil mainly in the Guaecá river, São Sebastião, state of São Paulo (type location of $M$. holthuisi), Rio Branco, Cananéia, state of São Paulo (type location of $M$. birai and $M$. petronioi) and Itajaí region, state of Santa Catarina (type location of $M$. potiuna) and Venezuela and preserved directly in $80 \%$ ethanol and deposited in the Crustacean Collection of the Departamento de Biologia, Faculdade de Filosofia, Ciências e Letras de Ribeirão Preto (FFCLRP), Universidade de São Paulo (USP). Species identifications were confirmed on the basis of morphological characters from available references (WIEGMANN, 1836; MÜLLER, 1880; Holthuis, 1952; GenOFRe \& LobÃo, 1978; LobÃo et al., 1986). The abbreviation "tl" is used to indicate the total length, measured from the tip of the rostrum to the end of the telson.

\section{RESULTS}

\section{Macrobrachium olfersi (Wiegmann, 1836) (Figs 1-15)}

Palaemon Olfersii Wiegmann, 1836:150.

Macrobrachium olfersi Holthuis, 1952:95; Melo, 2003:366; Melo \& BRossi-GARCIA, 2005:132.

Macrobrachium olfersii Holthuis \& Provenzano, 1970:212; Abele \& Kim, 1989:10; Ramos-Porto \& Coelho, 1998:334.

Macrobrachium holthuisi GENOFRE \& LoBÃo, 1978:273, fig. 1; Ramos-Porto \& Coelho, 1998:332; Melo, 2003:356. Syn. nov.

Macrobrachium birai LoBão, Melo \& Fernandes, 1986:50; Melo et al., 1988:89, figs. 1-4; Ramos-Porto \& Coelho, 1998:332; Melo, 2003:342. Syn. nov.

Material examined. Type material. Syntypes, $2 \AA$, BRAZIL, "Brazilian Coast", III.1836, A. F. Wiegmann leg. (MNB 1916). VENEZUELA, Nueva Esparta: Isla Margarita (Río Matasiete), $1 \partial^{\lambda}$, 30.VIII.2006, J. Lopez leg. (CCDB 2446). BRAZIL, Rio Grande do Norte: Umari (Rio Ceará Mirim), 2̧̂, 1ㅇ, 24.VII.2001, L. R. Malabarba \& H. Geórgia leg. (CCDB 3132); Nísia Floresta (Rio Ceceu), 3ㅊ, 1우, 20.VII.2001, L. R. Malabarba \& H. Geórgia leg. (CCDB 3131); Alagoas: Mundaú, 20, I.1985 (MZUSP 6631); Bahia: Rio Una, 10ิ, 22.III.1988, E. G. Mendes leg. (MZUSP 9252); Ilhéus (Rio Santana), 100, 4 9, 17.IX.2004, A. O. Almeida et al. leg. (CCDB 2439); 10, 1ㅇ, 20.V.2004, A. O. Almeida et al. leg. (CCDB 2495); Espírito Santo: Serra (Lagoa de Carapebus), 60, 02.VII.2005, P. Góes leg. (MZUSP 18843); Porto Cachoeira (Rio Santa Maria), 47, 1 , 19 우, 1906, E. Garbe leg. (MZUSP 203); Rio de Janeiro: Rio de Janeiro (Rio Guapiaçú, Cachoeira de Macacú), 1 đ̄, V.1929, R. Macedo leg. (MZUSP 5947); São Paulo: Ubatuba, 4 ${ }^{\lambda}$, 4, 01.XII.1982 (MZUSP 5969); (Rio Indaiá), 7 $\hat{\jmath}, 2+, 2$, + , 11.V.2005, L. G. Pileggi et al. leg. (CCDB 2425); (Rio do Instituto Oceanográfico da USP, Praia do Lamberto), 10ิ, 1, 25.IV.2005, L. G. Pileggi \& A. Costa leg. (CCDB 2480); 10, 2 ㅇ, 2 우, 03.V.2007, L. G. Pileggi \& A. Costa leg. (CCDB 2438); (Rio da Praia do Itaguá), $2 \hat{\jmath}, 6$ 우 우, 25.XI.2008, F. L. Mantelatto et al. leg. (CCDB 2473); (unnamed river, road/highway to Taubaté), 2ô, 13.VII.2006, F. L. Mantelatto \& L. G. Pileggi leg. (CCDB 2474); (unnamed river, road/highway to Taubaté, near Sabesp station), 1§̂, 13.VII.2006, F. L. Mantelatto \& L. G. Pileggi leg. (CCDB 2490); Caraguatatuba (Rio Claro), 12 우, 09.XI.2007, E. C. Mossolin et al. leg. (CCDB 2437); São Sebastião (Rio Guaecá), 1 $\hat{\delta}$, paratype of M. holthuisi, 23.VIII.1977, P. Sawaya leg. (RMNH.Crus 31709); 1 우, paratype of M. holthuisi, no date, V. Lobão leg. (MZUSP 5283); 53, 4ㅇ, 01.V.2006, F. L. Mantelatto et al. leg. (CCDB 2436); 4웅, 19.XI.2006, F. L. Mantelatto et al. leg. (CCDB 2476); 10 , 11.VII.2006, Mantelatto et al. leg. (CCDB 2435); (Rio São Pedro), 13, 01.V.2006, Mantelatto et al. leg. (CCDB 2449); (Rio do Curral), 13, 26.VI.2006, F. L. Mantelatto et al. leg. (CCDB 2138); (Rio do Sul da Praia Grande), 29, 01.V.2006, F. L. Mantelatto et al. leg. (CCDB 2138); (Rio Veloso), 3 , , 01.V.2006, F. L. Mantelatto et al. leg. (CCDB 2453); (Rio do Engenho d'água), 1 $\delta^{\lambda}, 7$ 오, 3 우우, 12.VII.2006, F. L. Mantelatto et al. leg. (CCDB 2434); (Rio da Toca), 1 ${ }^{\lambda}$, 20.VII.2006, F. L. Mantelatto et al. leg. (CCDB 2447); Córrego do Porto, $3 \hat{\jmath}, 1$ 우우, 09.III.1979, V. Lobão leg. (MZUSP 7166); Cananéia (Rio Branco), $1 \hat{\jmath}, 1$ 우우, 01.I.2001, S. Rocha leg. (MZUSP 15.820); 6수, 5우, 3 우우, 12.V.2008, F. L. Mantelatto et al. leg. (CCDB 2440); (Rio Branco, tributary of Rio Itapitangui), 1 , holotype of Macrobrachium birai, XII.1984, V. Lobão \& W. F. L. Fernandes leg. (MZUSP 8027); same as preceding except $6 \hat{0}$, paratypes of Macrobrachium birai (MZUSP $8028,8029,8030,8031,8032,8033$ ); same as preceding except $1{ }^{\lambda}$, 1 우 paratype of Macrobrachium birai (INPA-CR 274); Pariquera Açú (rio Iririaia Mirim), $6 \hat{0}, 5 \circ, 1$ 우, 18.IV.2011, F. L. Mantelatto et al. leg. (CCDB 3215); Iguape (Rio Ribeira de Iguape), 15 , 13.V.2008, F. L. Mantelatto et al. leg. (CCDB 2503); Miracatú (unnamed river, km 2,5, highway SP 222), 10, 2 2, 5 juveniles, 13.V.2008, F. L. Mantelatto et al. leg. (CCDB 2504); Parque Estadual da Ilha do Cardoso, 10 , 1 웅, 01.II.2001, S. Rocha \& F. Kyiohara leg. (MZUSP 15.097); Paraná: Antonina (Rio do Turvo), 10, 1qq, 01.IV.2003, C. Caluff leg. (CCDB 2445); Santa Catarina: Florianópolis (Rio Cachoeira do Sr. Jonato), $1 \hat{0}, 3$ 우, 5 웅, 10 juveniles, 17.IV.2007, F. L. Mantelatto et al. leg. (CCDB 1924); Florianópolis (Rio da Praia do Sambaqui), 20, 1 우, 1웅, 16.IV.2007, F. L. Mantelatto et al. leg. (CCDB 1922); Caieira do Norte (Rio da Cachoeira), 1§, 2 ㅇ, 2 우, 18.IV.2007, F. L. Mantelatto et al. leg. (CCDB 1929); Rio Grande do Sul: Torres (Rio Mampituba), 1ठ, 18.II.2009, C. K. Fukakusa leg. (UFRGS 4555).

Description. Rostrum (Figs 2, 6, 10) straight or slightly inclined downwards, sometimes rather narrow, not reaching, reaching or overreaching the end of antennular peduncle; upper margin with 12 to 16 teeth regularly divided, 3 to 6 placed on the carapace behind the orbit; first tooth separated from the second in a larger space of the others proximal; lower margin with 2 to 4 teeth. Inferior portion of the orbit convex and moderately reduced. Carapace smooth; hepatic spine smaller than antennal and placed in an oblique position. Thoracic sternum (T4) with a well developed median process, forming an acute tip. Scaphocerite somewhat less than three times as long as broad; outer margin straight or sometimes slightly concave or convex. Epistome bilobed, carinate, positioned obliquously in relation to the length of the carapace. Maxillula with bilobed endopodite; proximal lobe hooked with few setae and distal elongated without setae on the apex; basis with scattered setae and with two rows with strong spines on the apex; coxae with setae mainly on the apex; epipodite lobed starting from the basal portion. Second maxilliped operculiform, condyles of the carpus moderately produced over the propodus, propodus and dactylus strongly expanded posteriorly, covering the oral appendages; base with 
exopodite laminiform well developed (Figs 13.2, 14.2, 15.2). Third maxilliped elongated, basis, ischium and merus fused and distally extended with exopodite laminiform developed reaching the proximal end of the carpus; coxae with lobed epipodite; setae on all articles, mainly on the propodus and dactylus (Figs 13.3, 14.3, 15.3). First pereiopods (P1) reaching with half or with the proximal third of the carpus beyond the scaphocerite. Second pereiopods (P2) very unequal. The smaller one reaching with proximal third of the chelae or until half part of the carpus beyond the scaphocerite (fingers 1.5 times length of palm, bent to form a gap; cutting edges with a tooth in proximal part; both cutting edges with rigid and long setae directed inwardly, filling the gap between the fingers; palm slightly compressed and 1.5 times as long as wide; longitudinal rows of spinules present on the palm and fingers being the lower larger and more spaced; carpus slightly larger than palm and almost equal to merus; carpus and merus little swollen and provided with spinules as in the palm; ischium $3 / 4$ of the length of the merus). The larger one reaching with entire carpus or until with the distal third of the merus beyond the scaphocerite. Ischium half to $2 / 3$ as long as the merus. Merus swollen in the median portion; with longitudinal row of spines as in carpus, smaller and more dense dorsally, stronger and more spaced ventrally. Carpus strongly swollen anteriorly, constricted near the base; $2 / 3$ as long as the palm; about as long as the merus; about 2 times as long as high; rows of small spines dorsally. Propodus two times as long as the dactylus and two times as long as the carpus. Palm slightly compressed and swollen, with upper and lower margin superior and inferior convex; 1.5 to 2.5 times as long as high and about as long as the fingers; dense velvety pubescence on the inner, outer and lower surfaces. Fingers curved (especially the dactylus) forming a gap with long stiff hairs covering the gap; together with the palm, show a row of longitudinal spines that are smaller and more close in the outer part and stronger and more spaced in the inner part; lower margin of the chelae with a row of longitudinal strong spines, being stronger over the palm and decreasing of size toward the fingers; cutting edges with a strong tooth placed in the half of the length on the dactylus, and more proximally on the fixed tooth; 3 to 5 denticles between the strong tooth and the base of the fixed finger and 3 to 4 on the dactylus; sometimes 7 to 10 tubercles between the middle and the distal end of the fingers. Telson 1.5 times as long as the sixth abdominal segment; two pairs of dorsal spines placed in the middle and at $3 / 4$ of the length of the telson; posterior margin of the telson ending in a distinct acute tip which is reached or overreached by the inner of the two pairs of posterior spines. Inter-uropodal sclerite armed with a well-developed pre-anal carina (keel shape) (Figs 3, 4, $7,8,11,12)$.

Young and females. Lower number of rostrum teeth (1 to 3 ) placed on the carapace. P1 reaching with distal half of the chelae beyond the scaphocerite. P2 weaker and less unequal in size; young specimens with symmetric P2 reaching with the chelae beyond the scaphocerite; in females reach with distal third or until with half part of the carpus beyond the scaphocerite; fingers of the larger P2 without gap, closing in all extension; cutting edges almost smooth distally; pubescence and spinulation less distinct; all articles slender.

Type locality: Brazilian coast.

Distribution. Coastal river basins from the United States of America, Central America, Colombia, Venezuela, Guyana, Surinam and Brazil (states of Pará, Piauí, Ceará, Rio Grande do Norte, Pernambuco, Alagoas, Sergipe, Bahia to Rio Grande do Sul) (Melo, 2003).

Size. Males: tl 16 to $90 \mathrm{~mm}$; ovigerous females: tl 28 to $65 \mathrm{~mm}$.

Remarks. The type material ( 2 syntypes: MNB 1916) is deposited in the Museum für Naturkunde Berlin and is preserved as dry material and in good stage of conservation. The development of the three pairs of maxillipeds showed a similar pattern to the P2 heterochelous condition found in M. olfersi (see Mossolin \& Bueno, 2003). In this case, the exopodites from the base of the maxillipeds relative to the largest P2 side are more developed than the exopodites of the smaller one. This difference was observed in males with pronounced heterochely. In females and young males, in which this heterochely is not evident, almost no variation was found in the exopodites of the maxillipeds (Figs 1315). As far as we know, this observation is reported for the first time in members of Macrobrachium and should be explored the future morphological analysis.

In terms of general morphology, $M$. olfersi (Figs 1-4) is very similar to the presumptives $M$. birai (Figs 5-8) and M. holthuisi (Figs 9-12), as well as to other species from the "olfersi" group, as described by Villalobos (1969) (Tab. I).

The characters used to distinguish $M$. birai from M. olfersi (see Melo et al., 1988) are discussed: (1) "In M. olfersi, the teeth are regularly distributed in the upper margin of the rostrum and in M. birai the first tooth placed on the carapace is more spaced from the others". We normally found M. olfersi specimens with the first tooth more spaced from the others on the carapace, including the type material. This difference is not consistent and shows just a morphological variability; (2) "The tip of the fifth abdominal segment in $M$. birai is more acute than in M. olfersi". In general, we found a great variation in this character, being the tip acute or sometimes less acute. This difference is not consistent and reflects just a morphological variability; (3) "The $\mathrm{P} 1$ chelae is half as long as the carpus in $M$. olfersi and $1 / 3$ in $M$. birai". In contrary, considering the presumptive $M$. birai specimens studied, including the type material, the carpus is two times as long as 
Tab. I. Comparison between Macrobrachium olfersi (Wiegmann, 1836), Macrobrachium birai Lobão, Melo \& Fernandes, 1986, Syn. nov. and Macrobrachium holthuisi Genofre \& Lobão, 1978, Syn. nov.

\begin{tabular}{|c|c|c|c|}
\hline Character & M. olfersi & M. birai & M. holthuisi \\
\hline $\begin{array}{l}\text { Distribution of the teeth on the } \\
\text { upper margin of the rostrum }\end{array}$ & $\begin{array}{l}\text { regularly distributed or with the } \\
\text { first tooth placed on the carapace } \\
\text { more spaced from the others }\end{array}$ & $\begin{array}{l}\text { with the first tooth placed on the } \\
\text { carapace more spaced } \\
\text { from the others }\end{array}$ & regularly distributed \\
\hline Tip of the fifth abdominal segment & acute & acute & acute \\
\hline P1 length & $\begin{array}{l}\text { overreach with the distal end of } \\
\text { the carpus until with the distal } \\
\text { third of the carpus beyond the } \\
\text { scaphocerite }\end{array}$ & $\begin{array}{l}\text { overreach with the distal } \\
\text { third of the carpus beyond the } \\
\text { scaphocerite }\end{array}$ & $\begin{array}{l}\text { reach with the distal end of the } \\
\text { carpus beyond the scaphocerite }\end{array}$ \\
\hline P1 chelae length & half as long as the carpus & half as long as the carpus & half as long as the carpus \\
\hline Ratio carpus/merus of $\mathrm{P} 1$ & 1 until 1.3 times as long as the carpus & 1.25 times as long as the carpus & 1 until 1.25 times as long as the merus \\
\hline Females P1 length & $\begin{array}{l}\text { reach with the carpus } \\
\text { (sometimes with the fingers) the } \\
\text { end of the scaphocerite }\end{array}$ & $\begin{array}{l}\text { reach with the carpus the end of } \\
\text { the scaphocerite }\end{array}$ & $\begin{array}{l}\text { reach with the fingers the end } \\
\text { of the scaphocerite }\end{array}$ \\
\hline Larger P2 length & $\begin{array}{l}\text { reach with part of the merus } \\
\text { beyond the scaphocerite }\end{array}$ & $\begin{array}{l}\text { reach with part of the merus } \\
\text { beyond the scaphocerite }\end{array}$ & $\begin{array}{l}\text { reach with half of the carpus } \\
\text { beyond the scaphocerite }\end{array}$ \\
\hline Ischium length of the larger P2 & $1 / 3$ until $1 / 2$ of the merus & $1 / 2$ of the merus & $1 / 3$ of the merus \\
\hline Ratio of length/height of the $\mathrm{P} 2$ palm & 1.5 until 2.5 times & 2 times & 2 times \\
\hline Palm of the chelae of the larger P2 & $\begin{array}{l}\text { distinctly compressed to } \\
\text { completely inflated }\end{array}$ & inflated & $\begin{array}{l}\text { distinctly compressed and not } \\
\text { inflated as in } M \text {. olfersi }\end{array}$ \\
\hline The inner surface of the $\mathrm{P} 2$ palm & $\begin{array}{l}\text { with spines (sometimes } \\
\text { spinules) on the proximal and } \\
\text { distal third or without spines }\end{array}$ & $\begin{array}{l}\text { with spines on the proximal and } \\
\text { distal third }\end{array}$ & $\begin{array}{l}\text { with spinules on the proximal } \\
\text { and distal third }\end{array}$ \\
\hline Ratio Palm/dactylus & $\begin{array}{l}\text { palm with the same size or } \\
\text { smaller than the dactylus }\end{array}$ & palm smaller than the dactylus & same size \\
\hline $\begin{array}{l}\text { Spinulation on the lower margin } \\
\text { of the chelae of larger P2 }\end{array}$ & weak to strong & strong & weak \\
\hline P2 fixed finger & $\begin{array}{l}\text { with or without tricuspid molar } \\
\text { (in some cases with } 5 \text { fused } \\
\text { denticles) behind the larger tooth }\end{array}$ & $\begin{array}{l}\text { with tricuspid molar behind the } \\
\text { larger tooth }\end{array}$ & without tricuspid molar \\
\hline Fingers of $\mathrm{P} 2$ & $\begin{array}{l}\text { slightly curved without gap to } \\
\text { strongly curved forming a gap } \\
\text { (mainly the dactylus) }\end{array}$ & $\begin{array}{l}\text { strongly curved forming a gap } \\
\text { (mainly the dactylus) }\end{array}$ & slightly curved without gap \\
\hline Females P2 spinulation of the palm & more reduced or the same of the males & more reduced or the same of the males & more reduced than the males \\
\hline Females P2 carpus & 3 times as long as broad & 3 times as long as broad & 3 times as long as broad \\
\hline P5 propodus length & 3.5 times as long as the dactylus & 3.5 times as long as the dactylus & 3.5 times as long as the dactylus \\
\hline
\end{tabular}

the chelae; (4) Cutting edges of the larger P2 "fixed finger in $M$. olfersi without tricuspid molar behind the larger tooth, as is found in M. birai". In our material we observed 3 to 5 denticles more or less spaced and fused on the base. Then, the variation of the "molar" with 3, 4 and 5 denticles is usual inside $M$. olfersi; (5) "The ratio length/height of the $\mathrm{P} 2 \mathrm{palm}$ is 1.5 times in $M$. olfersi and 2 times in M. birai". In the M. olfersi specimens analyzed, i.e. from several sizes, this ratio ranged from 1.5 to 2.5 , which invalidates this ratio as a diagnostic character; (6) "The inner surface of the P2 palm without spines in $M$. olfersi and with spines on the proximal and distal third in M. birai". The absence of spines was not observed in the studied specimens, which has spines on the palm; (7) "P5 propodus is 3 times as long as the dactylus in $M$. olfersi and 4 times in M. birai". Our analysis showed that in both species the propodus of P5 is 3.5 times as long as the dactylus; (8) "In females P1 reach with the fingers the end of the scaphocerite in $M$. olfersi and with the

carpus in M. birai". This variation seems to be related to the ontogenetic stage of the animal, because this amplitude of variation was observed in specimens previously assigned to both species; (9) "In females the spinulation of the palm of the larger chelae of P2 is the same of the males in M. olfersi and more reduced and equally distributed in M. birai". Again, this difference seems to be related to the ontogenetic stage of the animal; (10) "In females the carpus of the larger chelae is 3 times as long as broad in $M$. olfersi and 4 times in M. birai". We did not observe this difference in our revision.

The characters used to separate $M$. holthuisi from M. olfersi (see Genofre \& Lobão, 1978) are discussed: (1) "The larger P2 reach with half of the carpus beyond the scaphocerite in $M$. holthuisi and with part of the merus in $M$. olfersi". This difference is not consistent, since we found various specimens of $M$. olfersi with $\mathrm{P} 2$ reaching with half to the distal third of the carpus, beyond the scaphocerite. The observed 

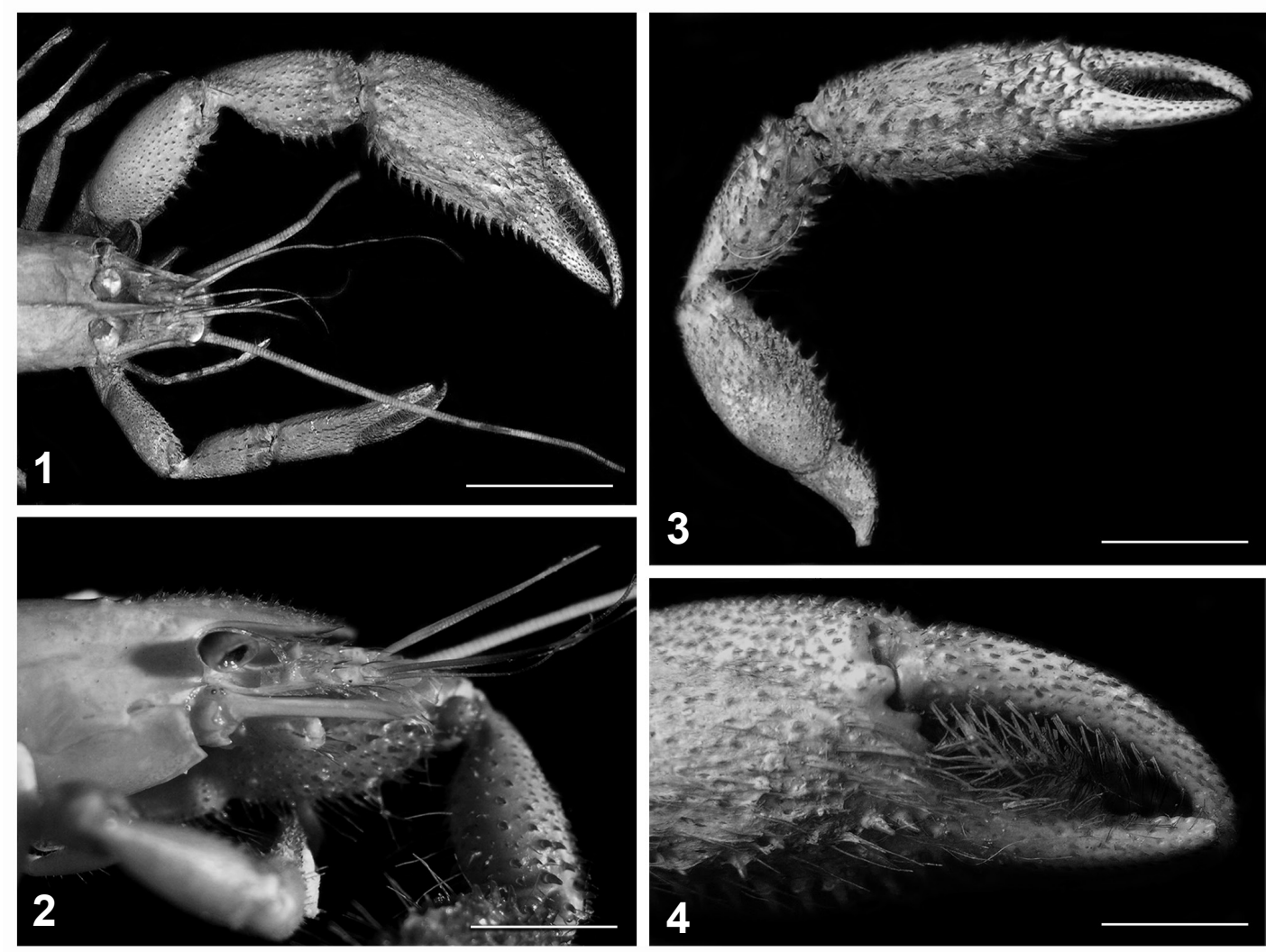

Figs 1-4. Macrobrachium olfersi (Wiegmann, 1836), syntype male (MNB 1916 - cl: $23.60 \mathrm{~mm}$ ): 1, dorsal view of the anterior portion; 3 , largest P2; 4, largest P2 finger; male (CCDB 2489 - cl: $19.82 \mathrm{~mm}$ ): 2, lateral view of the rostrum. Scale bars: Fig. 1, 15 mm; Fig. 2, 9 mm; Fig. 3 , 12 mm; Fig. 4, $5 \mathrm{~mm}$.
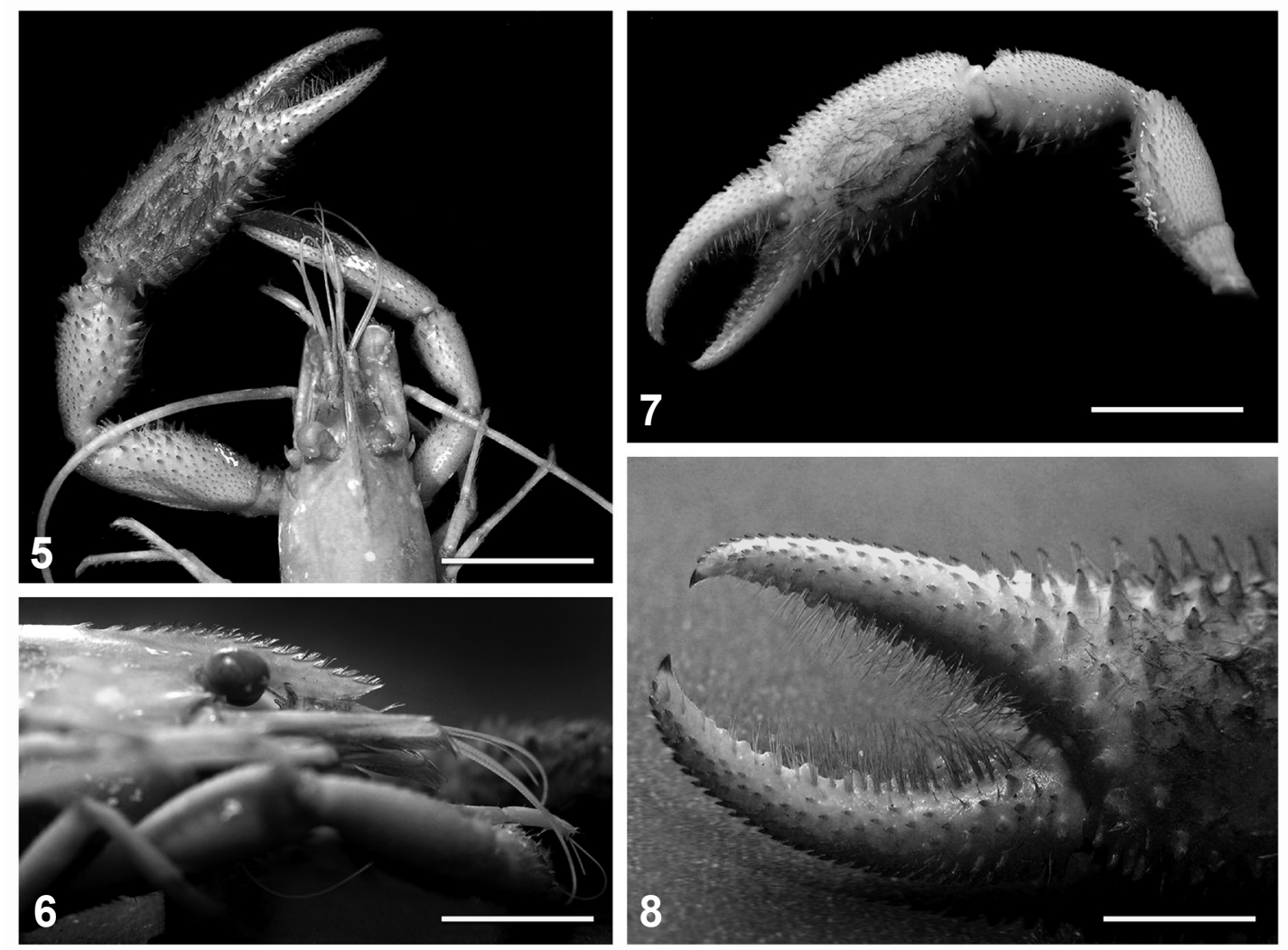

Figs 5-8. Macrobrachium olfersi (Wiegmann, 1836), holotype male of Macrobrachium birai Lobão, Melo \& Fernandes, 1986, Syn. nov. (MZUSP 8027): 5, dorsal view of the anterior portion; 6, lateral view of the rostrum; 7, largest P2; 8, largest P2 finger. Scale bars: Fig. 5, 14 mm; Fig. 6 , $10 \mathrm{~mm}$; Fig. 7, $18 \mathrm{~mm}$; Fig. $8,7 \mathrm{~mm}$. 

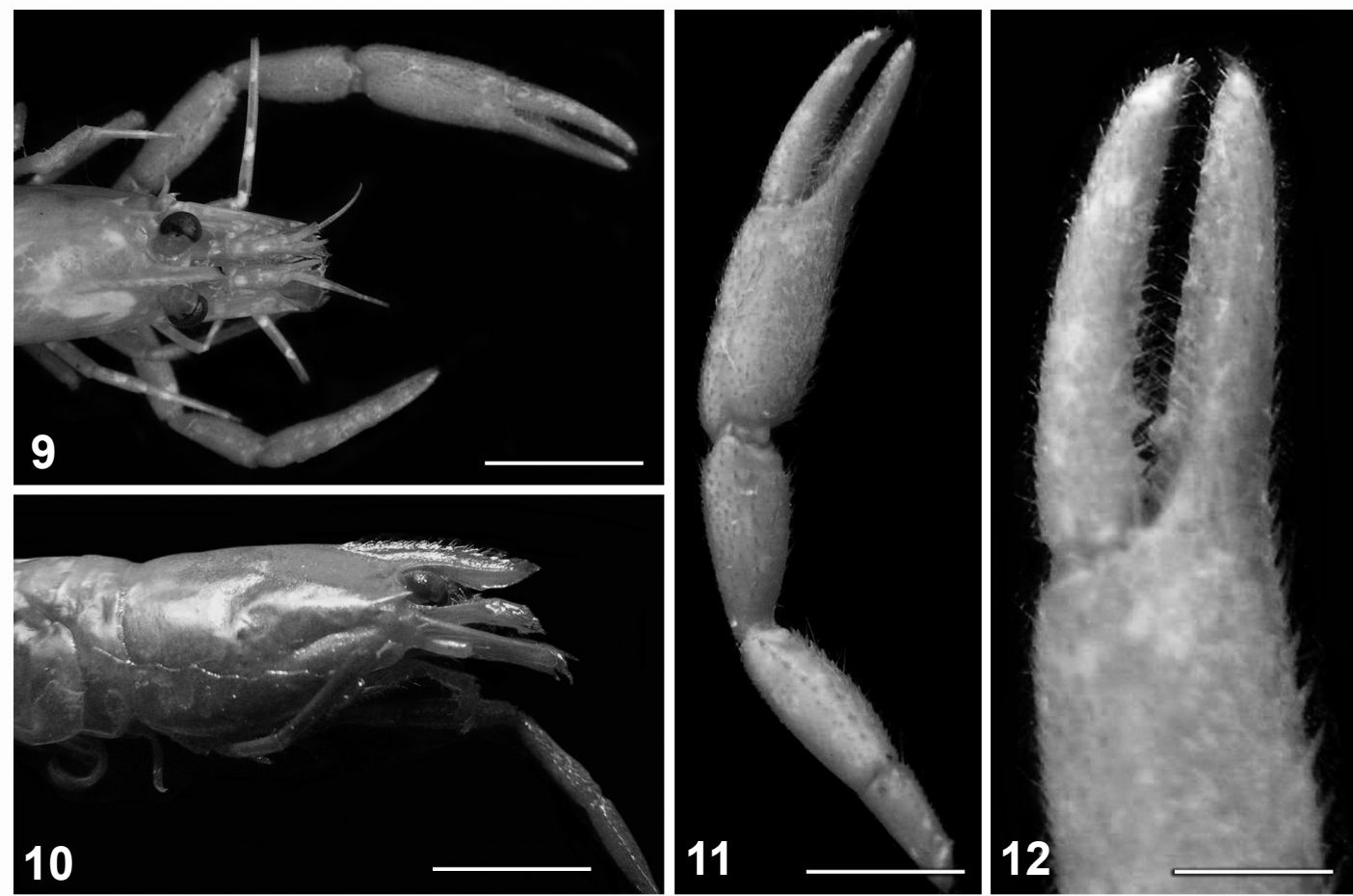

Figs 9-12. Macrobrachium olfersi (Wiegmann, 1836), paratype male of Macrobrachium holthuisi Genofre \& Lobão, 1978, Syn. nov. (RMNH D 31709): 9, dorsal view of the anterior portion; 11, largest P2; 12, largest P2 finger; paratype female (ovigerous) (MZUSP 5283): 10, lateral view of the rostrum. Scale bars: Fig. 9, 8 mm; Fig. 10, 6 mm; Fig. 11, 4 mm; Fig. 12, $1 \mathrm{~mm}$.

variation seems to be related with the ontogenetic stage of the animal; (2) "Lower margin of the chelae of larger $\mathrm{P} 2$ with spinulation not as strong as in $M$. olfersi. The setae of the chelae are less numerous and of the smaller size in M. holthuisi". Such situation is normally found in specimens of $M$. olfersi and clearly is related with the ontogenetic stage of the animal; (3) "Palm of the chelae of the larger P2 distinctly compressed and not inflated as in $M$. olfersi". This character was found in $M$. olfersi males with little developed chelae or in young males; (4) "Ischium of the larger P2 is $1 / 3$ smaller than the merus in $M$. holthuisi and with $1 / 2$ of the merus in $M$. olfersi". In our specimens the ischium of P2 is half to $2 / 3$ as long as the merus. Therefore, this difference is not consistent; (5) "Fingers of P2 slightly curved without gap and with palm and dactylus of the same size in M. holthuisi. In $M$. olfersi the fingers, mainly of the dactylus, are curved forming a gap and the palm is smaller than the dactylus". These differences are not consistent as they could be assigned to the developmental stage of the species; (6) "In $M$. holthuisi P1 reach with the distal end of the carpus beyond the scaphocerite and in $M$. olfersi overreach with the distal third of the carpus". Such development of P1 is commonly found in young males and in less developed males of $M$. olfersi; (7) "Carpus of P1 is 1.1 time as long as the merus in $M$. holthuisi and the merus is $4 / 5$ of the carpus in $M$. olfersi". In contrary, considering the presumptive $M$. holthuisi specimens studied, including the type material, the merus is $4 / 5$ until the same length of the carpus. Thus, this character is very variable and not reliable as a diagnostic character.

\section{Macrobrachium potiuna (Müller, 1880)}

(Figs 16-23)

\section{Palaemon potiuna Müller, 1880:152.}

Macrobrachium potiuna Holthuis, 1952:76; Ramos-Porto \& CoElHo, 1998:335; Melo \& Brossi-Garcia, 1999:623; Melo, 2003:370.

Macrobrachium petronioi Melo, LoBÃo \& Fernandes, 1986:51; Melo, Lobão \& Fernandes, 1988:92; Ramos-Porto \& Coelho, 1998:334; Melo, 2003:368. Syn. nov.

Material examined. BRASIL, Bahia: Una (Ribeirão Rosário) 2ð, 29 , , 19.X.2010, A. O. Almeida, A. Cunha, G. Soledade \& P. Souza leg. (UESC 1348); (Córrego São Caetano), 4ð, 2 우, 19.X.2010, A. O. Almeida, A. Cunha, G. Soledade \& P. Souza leg. (UESC 1357); same as preceding except $3 \hat{\jmath}, 2$ 우 (UESC 1359); Porto Seguro (Tributary of the stream Ronca, Estação Veracel), $2 \hat{\jmath}, 3$ ㅇ, 1 우, 16.VIII.2011, F. L. Carvalho \& E. A. Carvalho leg. (CCDB 1662); Rio de Janeiro: Itaguaí, 1今, IX.1963, C. Queiroz leg. (MZUSP 9839); São Paulo: Ubatuba (Rio Monte Valero, alternative road to Ubatuba via Praia Dura mangrove, $9 \mathrm{~km}$ of BR 101 highway), $5 \widehat{\jmath}, 4$ 우, 1 우우, 17.IX.2008, F. L. Mantelatto et al. leg. (CCDB 2454); same as preceding except $18 \hat{\jmath}, 10 \circ, 14$ 우 (CCDB 2455); same as

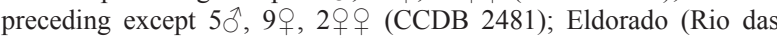
Ostras, Caverna do Diabo), 4خे, 2 + $9,01$. X.2004, E. C. Mossolin. leg. (CCDB 2131); Cananéia (Rio Branco), 10 đ, 30.VII.2001, S. Rocha et al. leg. (MZUSP 15819); 4ત, 01.IX.2004, E. C. Mossolin. leg. (CCDB

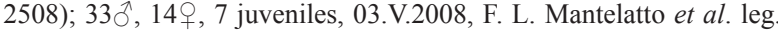
(CCDB 2456); Cananéia (Rio Branco, tributary of Rio Itapitangui), $1 \widehat{ }$, holotype of Macrobrachium petronioi, XII.1984, V. Lobão \& W. Fernandes leg. (MZUSP 8034); same as preceding except $1 \hat{\jmath}$, paratype of Macrobrachium petronioi (MZUSP 8035); same as preceding except 1 (을 (MZUSP 8037); same as preceding except 1 , , paratype of Macrobrachium petronioi (MZUSP 8038); same as preceding except $1 \widehat{\jmath}, 1$ 우, paratype of Macrobrachium petronioi (INPA-CR 275);

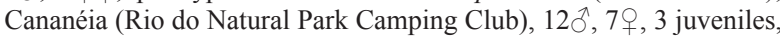
12.V.2008, F. L. Mantelatto et al. leg. (CCDB 2500); Pariquera Açú (Rio Iririaia Mirim), 2§, 2 , 7 juveniles, 18.IV.2011, F. L. Mantelatto et al. leg. (CCDB 3214); Ex-Colônia Itapitangui (unnamed river), 4ત, 4, 1 juvenile, 12.V.2008, F. L. Mantelatto et al. leg. (CCDB 2501); Iguape (unnamed river, km 14, Rod. 222), $15 \hat{\jmath}, 28$ +, 6 juveniles, 13.V.2008, 

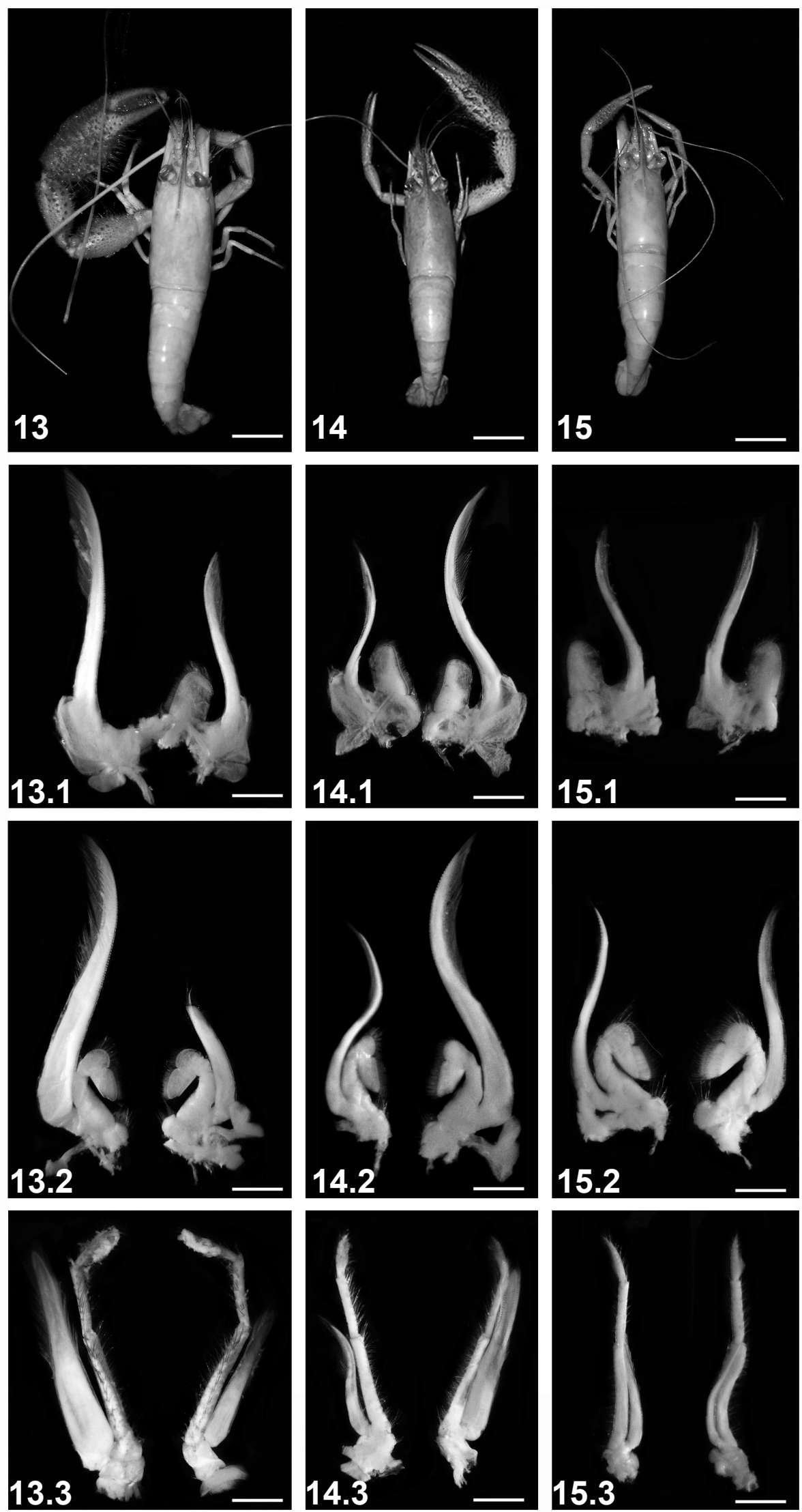

Figs 13-15. Different sizes of the exopodites of Macrobrachium olfersi (Wiegmann, 1836). 13, male (CCDB 2489) with well-developed P2: 13.1, first pair of maxillipeds; 13.2, second pair of maxillipeds; 13.3, third pair of maxillipeds; 14, male (CCDB 2452) with moderately developed P2: 14.1, first pair of maxillipeds; 14.2, second pair of maxillipeds; 14.3, third pair of maxillipeds; 15, ovigerous female (CCDB 2424) with weak developed P2: 15.1, first pair of maxillipeds; 15.2, second pair of maxillipeds; 15.3, third pair of maxillipeds. Scale bars: Figs 13-15, 7 mm; Figs 13.1-15.3, 0.5 mm. 
F. L. Mantelatto et al. leg. (CCDB 2496); Tapiraí (unnamed river, km 161, Rod. 079), 13 $\partial_{1} 120,7$ juveniles, 12.V.2008, F. L. Mantelatto et

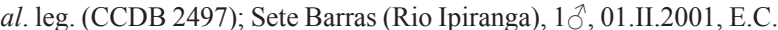
Mossolin leg. (MZUSP 13561); Paraná: Antonina (Rio do Turvo), 13, 1 우, 01.IV.2003, C. Calluf et al. leg. (CCDB 2132); Antonina (Rio Barroca, Baia Antonina), 4ㅇ, 1 웅, 17.III.2007, J. K. Nagata leg. (CCDB 2002); Piraquara (Rio Piraquara), 30 , 01.VI.2008, E. Oliveira \& E. B. Cardon leg. (CCDB 2471); same as preceding except $1 \partial^{\lambda}, 2$ 우 (CCDB 2472); Santa Catarina: Garuva, 2へ, 07.X.2003, G. Bond Buckup \& L. Buckup leg. (UFRGS 2659); Joinville (Rio Pirabeiraba),

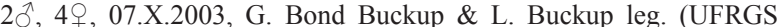
2649); Blumenau (Parque Natural Municipal São Francisco de Assis),

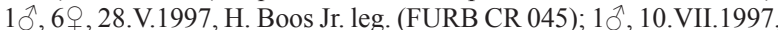
H. Boos Jr. leg. (FURB CR 216); 8ㅇ, 24.VII.1997, H. Boos Jr. leg. (FURB CR 213); 19 , 31.VII.1997, H. Boos Jr. leg. (FURB CR 203); 6ㅇ, 13.VIII.1997, H. Boos Jr. leg. (FURB CR 210); 17우, 27.VIII.1997, H. Boos Jr. leg. (FURB CR 214); 229, 10.IX.1997, H. Boos Jr. leg. (FURB CR 206); 37ô, 16ㅇ, 13.X.1997, H. Boos Jr. leg. (FURB CR 219); 14ð, 27.X.1997, H. Boos Jr. leg. (FURB CR 202); 3 q, 21.I.1998, H. Boos Jr. leg. (FURB CR 205); 37ð, 14.IV.1998, H. Boos Jr. leg. (FURB CR 131); 50 , 31.VIII.1998, H. Boos Jr. leg. (FURB CR 127); 2 , 06.I.1999, H. Boos Jr. leg. (FURB CR 124); Itajaí (Rio Espinheirinho), 60 15 , 4 juveniles, 19.IV.2007, F. L. Mantelatto et al. leg. (CCDB 1921); Florianópolis (Parque Municipal, Lagoa Peri), 10, 31.X.2006, D. Ammar leg. (CCDB 1859); same as preceding except 1 우 (CCDB 1860)

Description. Rostrum straight and rather high, sometimes rather narrow; reaching (sometimes not reaching) the end of antennular; upper margin with 6 to 10 teeth regularly divided, 1 to 2 of which placed on the carapace behind the orbit; first tooth separated from the second in a larger space than the space between the proximal ones; lower margin with 1 to 3 teeth (Figs 17, 21). Inferior portion of the orbit convex and well produced anteriorly, almost forming an acute tip. Scaphocerite 2.5 to 3 times as long as broad; outer margin straight, sometimes slightly convex. Epistome bilobed, carinate, positioned obliquously in relation to the length of the carapace. Maxillula with bilobed endopodite; proximal lobe hooked without setae; distal elongated with few setae on the apex; base with scattered setae and with two rows of strong spines on the apex; coxae with setae mainly on the apex; epipodite lobed. Second maxilliped operculiform, condyles of the carpus moderately produced over the propodus, propodus and dactylus strongly expanded posteriorly, covering the buccal appendices; base with exopodite laminiform well developed. Third maxilliped elongated; base, ischium and merus fused and distally extended; exopodite laminiform, well developed, reaching the proximal end of the carpus; coxae with lobed epipodite; setae in all articles, mainly on propodus and dactylus. Carapace roughened with numerous spinules in the antero-lateral portion; hepatic spine smaller than the antennal and placed in an oblique position. Thoracic sternum (T4) with reduced median process. First pereiopods (P1) reaching, with half of the carpus until the tip of the chelae beyond the scaphocerite. Second pereiopods (P2) equal in shape, rather unequal in size; reaching with distal third or entire carpus beyond the scaphocerite; spines in all articles. Ischium $2 / 3$ to $3 / 4$ as long as the merus. Merus as long
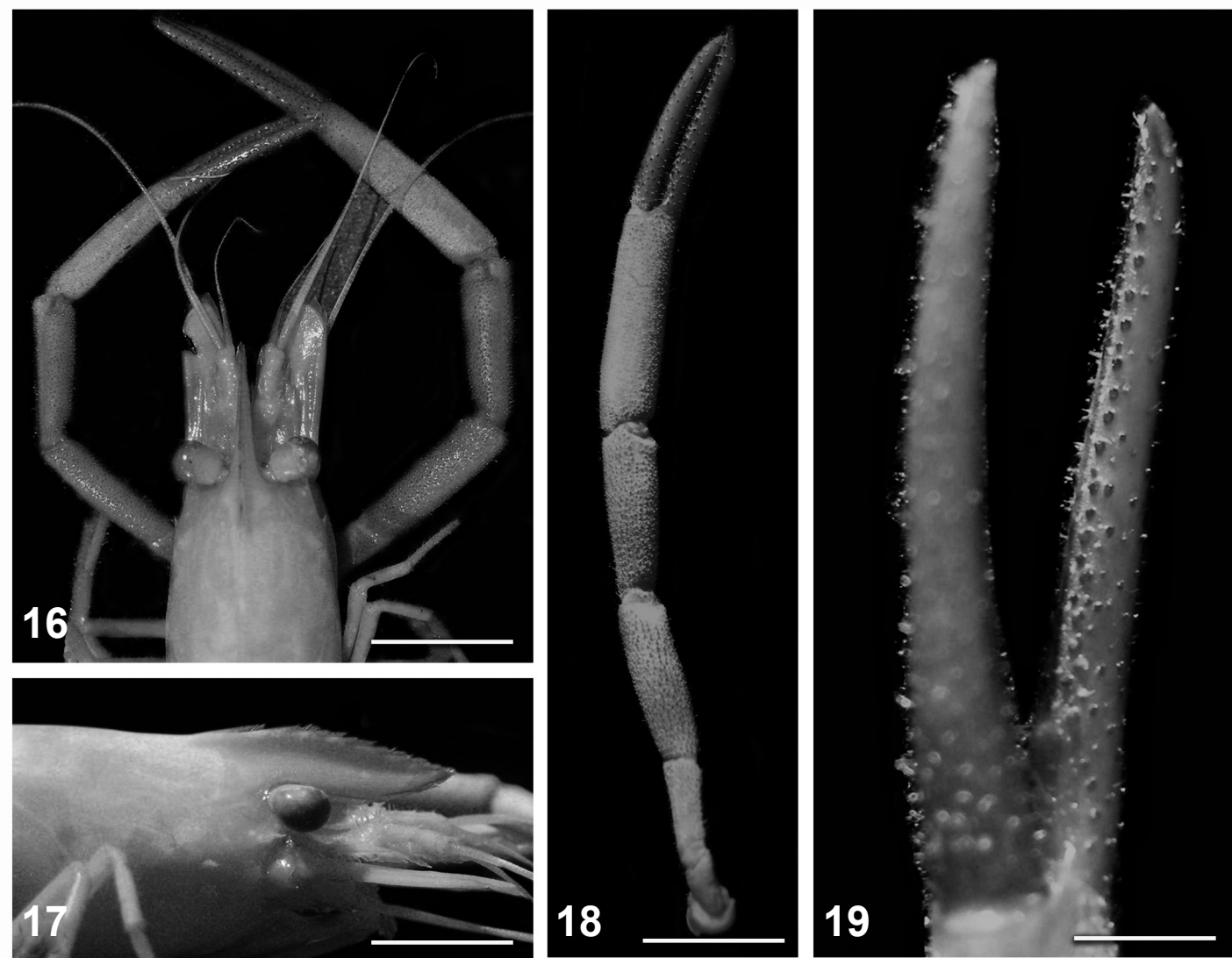

Figs 16-19. Macrobrachium potiuna (Müller, 1880), male (CCDB 2131): 16, dorsal view of the anterior portion; 17, lateral view of the rostrum; 18, largest P2; 19, largest P2 finger. Scale bars: Fig. 16, 6 mm; Fig. 17, 5 mm; Fig. 18, 9 mm; Fig. 19, 2 mm. 

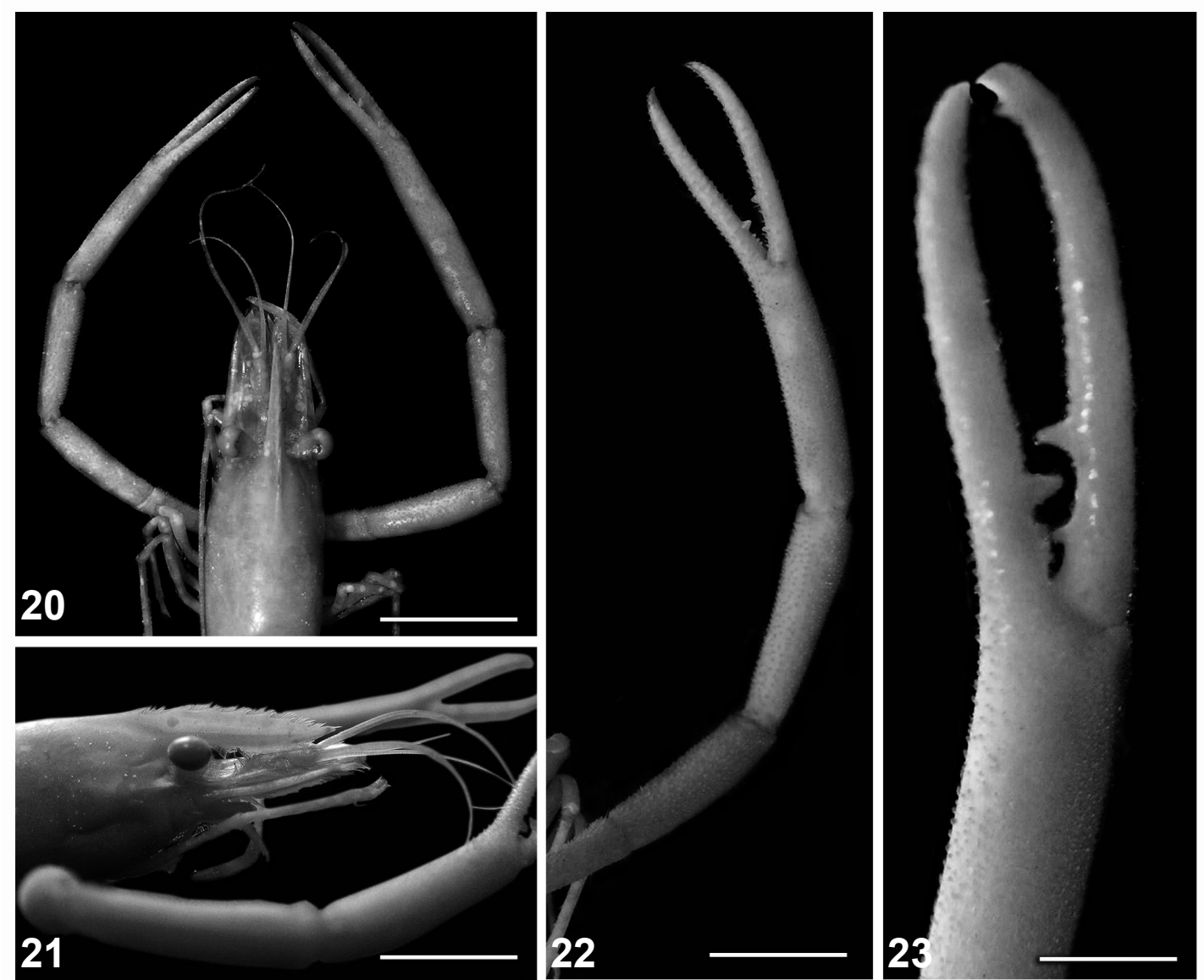

Figs 20-23. Macrobrachium potiuna (Müller, 1880), holotype male of Macrobrachium petronioi Melo, Lobão \& Fernandes, 1986, Syn. nov. (MZUSP 8034): 20, dorsal view of the anterior portion; 21, lateral view of the rostrum; 22, largest P2; 23, largest P2 finger. Scale bars: Fig. 20,6 mm; Fig. 21, 5 mm; Fig. 22, 4 mm; Fig. 23, 1.5 mm.

Tab. II. Comparison between Macrobrachium potiuna (Müller, 1880) and Macrobrachium petronioi Melo, Lobão \& Fernandes, 1986, Syn. nov.

\begin{tabular}{|c|c|c|}
\hline Character & M. potiuna & M. petronioi \\
\hline $\begin{array}{l}\text { Distribution of the teeth on the upper margin } \\
\text { of the rostrum }\end{array}$ & 1 or 2 teeth behind the orbit & 1 tooth behind the orbit \\
\hline Cutting edges of the $\mathrm{P} 2$ fingers & $\begin{array}{l}\text { smooth or filled by } 2 \text { rows of denticles } \\
\text { between the strong teeth and the distal end }\end{array}$ & $\begin{array}{l}\text { smooth or filled by } 2 \text { rows of denticles } \\
\text { between the strong teeth and the distal end }\end{array}$ \\
\hline Relation length/width of the scaphocerite & 2.5 times & 2.5 to 3 times \\
\hline Relation P2 fingers/palm & smaller until larger than the palm & smaller than the palm \\
\hline P3 length & $\begin{array}{l}\text { not reach, reach or overreach with the } \\
\text { dactylus the end of the scaphocerite }\end{array}$ & reach the end of the scaphocerite \\
\hline P5 length & reach the distal third of the scaphocerite & reach the distal third of the scaphocerite \\
\hline
\end{tabular}

as the carpus, covered with spinules, without pubescence. Carpus $2 / 3$ to $3 / 4$ as long as the palm, covered with spinules, without pubescence. Propodus 2 times as long as the dactylus and 2 to 2.5 times as long as the carpus. Palm elongated, slightly compressed, with spinules in the outer, inner and lower margins; posterior end almost naked with scattered setae. Fingers elongated, thin, slightly curved, forming small gap; cutting edge of the dactylus with 2 strong teeth in the proximal part; fixed finger with 1 strong tooth between the 2 of the dactylus, proximal end with denticles toward the base; sometimes mesial margin of the fingers with row of about 20 tubercles; fingers surface with spinules (Figs 18, 19, 22, 23). Telson 1.5 times as long as sixth abdominal segment; two pairs of dorsal spines placed in the middle and at $3 / 4$ of the length of the telson. Posterior margin of telson ending in distinct acute tip; telson with two pairs of posterior spines, inner pair reaching or overreaching the median tip; numerous setae between inner posterior spines. Inter-uropodal sclerite armed with weakly developed pre-anal carina.

Young and females: Carapace smooth; P2 relatively smaller than in males and almost naked; equal in shape and size, reaching with distal third of the carpus beyond the scaphocerite; fingers of P2 without gap, closing along the entire length; cutting edges with teeth as in adult males but less developed or nearly smooth.

Type locality: Itajaí River, Blumenau, SC, Brazil

Distribution. Inland waters from Brazil (states of 
Mato Grosso, Minas Gerais, Bahia to Rio Grande do Sul) (Melo, 2003; Carvalho et al., in press).

Size. Males: tl 16 to $60 \mathrm{~mm}$; ovigerous females: tl 31 to $50 \mathrm{~mm}$.

Remarks. In the original description, MüLLER (1880) did not mention the deposit of type material. HoLthuIs (1952) cited that Turin Museum has 3 specimens from Blumenau, Santa Catarina collected by F. Müller. Unfortunately, during our visit to that collection, those specimens were not found, and we believe that they no longer exist. In the present work, we collected specimens in an area close to the type locality (lot CCDB 1921), but not in the Itajaí River, which is highly impacted in some parts by sewerage outflows, and the region is subject to farming and harbor activities as well. The effects of that impact are easily seen in the type locality, which has been intensively modified and degraded by anthropogenic activities. All those factors have probably impacted the local flora and fauna. Since the type material seems to be disappeared a designation of a neotype is required (L. G. Pileggi, pers. observ.).

The morphological similarity between the holotype of M. petronioi (Figs 20-23) and specimens of M. potiuna (Figs 16-19) is very pronounced (Table II). The characters used to separate $M$. petronioi from M. potiuna (see Melo et al., 1988) are discussed: (1) "Macrobrachium petronioi with 1 tooth behind the orbit and with 2 in M. potiuna". Such difference is not reliable, since we usually found 1 or 2 teeth placed on the carapace behind the orbit in M. potiuna; (2) "Cutting edges of the $\mathrm{P} 2$ fingers smooth between the strong teeth and the distal end in M. potiuna, and in M. petronioi this portion is filled by 2 rows of denticles". Such difference could not be corroborated as we found many presumptive specimens, including type material of $M$. petronioi with cutting edges distally smooth. In addition, mature males of M. potiuna presents the $\mathrm{P} 2$ with these 2 rows of denticles (called tubercles); (3) "The relation length/width of the scaphocerite is 2.5 times in M. potiuna and more than 3 times in M. petronioi". This relation is not reliable to separate both species, since we found presumptive specimens, including type material of $M$. petronioi ranging from 2.5 to 3 times; (4) "P2 with fingers larger than the palm in M. potiuna and, in opposite, the palm is larger than the fingers in $M$. petronioi". We usually found specimens of M. potiuna with fingers of $\mathrm{P} 2$ smaller than the palm. Therefore, this character is not consistent for diagnostic purpose; (5) "In M. potiuna P3 overreach with the dactylus the end of the scaphocerite, and in M. petronioi just reach the end of the scaphocerite". This could not be verified as the P3, in M. potiuna, can vary from not reaching, reaching or overreaching the end of the scaphocerite; (6) "P5 in M. potiuna reach the end of the scaphocerite, and in M. petronioi just reach the middle of the scaphocerite". The variability of this character seems to be related to the developmental stage of the animal or simply correspond to an intraspecific variation. In mature males of $M$. potiuna, $\mathrm{P} 5$ reach the distal third of the scaphocerite, as they do in presumptive mature males of $M$. petronioi, including type material.
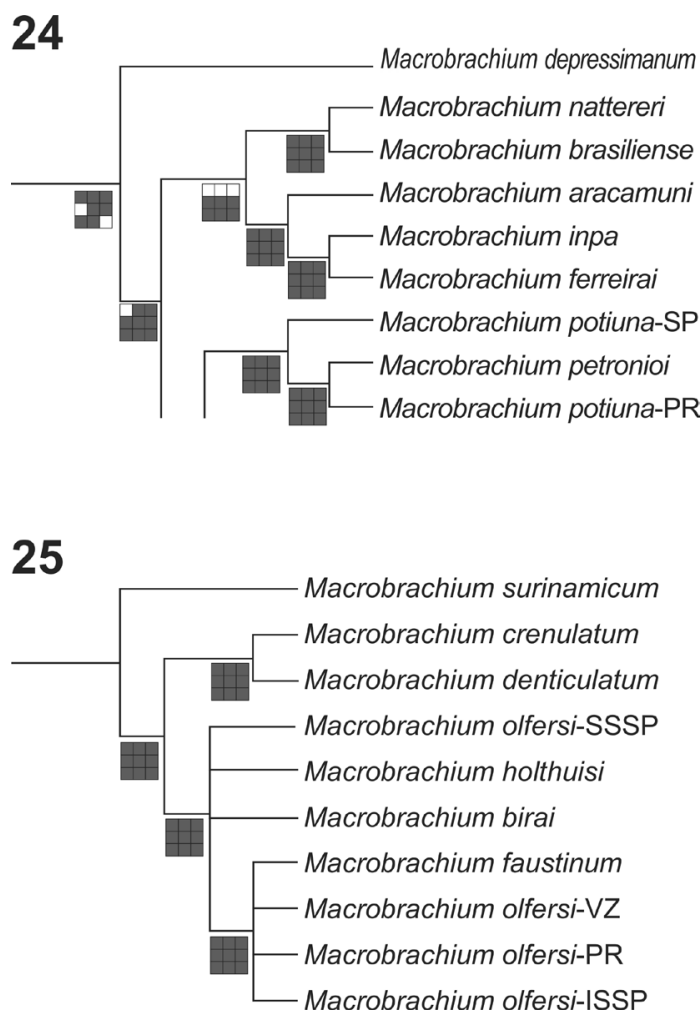

Figs 24-25. Parts of the phylogenetic tree modified of PILEGGI \& MANTELATto (2010): 24, clade that include $M$. petronioi together with $M$. potiuna; 25 , clade that include $M$. birai and $M$. holthuisi together with $M$. olfersi, based on direct optimization analysis of 16S rDNA. The box at the nodes indicates the parameter sets used in the analysis. Filled boxes signify that the clade was present (ISSP, Ilha de São Sebastião São Paulo; PR, Paraná; SP, São Paulo; SSSP, São Sebastião, São Paulo; VZ, Venezuela).

\section{DISCUSSION}

Our comparison of morphological characters revealed no diagnostic differences between the three putative species M. olfersi, M. birai and M. holthuisi. The morphology suggests very close relationships between members within this group, and led Villalobos (1969) to classify these species as belonging to the "olfersi" group. This high morphological similarity makes taxonomic resolution difficult (Ostrovski et al., 1996).

According to our revision, the characters used to distinguish $M$. olfersi from M. birai could be explained by the high level of intraspecific variation found in Macrobrachium species, allied to the possible existence of morphotypes in $M$. olfersi, as described for other species of the genus (Kuris et al., 1987; MoraesRiodades \& Valenti, 2004; Wortham \& Van Maurik, 2012). The morphological results corroborated the previous genetic analysis (PilegGi \& Mantelatto, 2010) that also indicated the great similarity between these species (Fig. 25). The genetic divergence of M. birai and $M$. olfersi specimens showed an intraspecific variation level for $16 \mathrm{~S}$ gene. In the same study, we presented a phylogeny of the genus Macrobrachium in which the positioning of these species corroborates our present morphological proposition (Figs 24, 25). 
In the same way, the differences used to separate $M$. olfersi from $M$. holthuisi seem to be related to the ontogenetic stage of the animals. By examining the type material of $M$. holthuisi, we concluded that either it was described from undeveloped males, or the specimens correspond to a morphotype of $M$. olfersi associated to a position in a possible social hierarchic on the population. The previous genetic analysis (PilegGi \& Mantelatto, 2010) also pointed the high similarity of $M$. holthuisi compared with $M$. olfersi specimens (Fig. 25). Recent results obtained from larval morphology of supposedly identified as M. birai (Melo \& Brossi-Garcia, 2005) evidenced the similarity with the larvae of $M$. olfersi previously described (Dugger \& Dobkin, 1975). Some minor differences pointed in different zoeal stages in terms of morphology of antenna, antennules, maxilla, maxillipeds and pereiopods between both species did not provide convinced characters to support the separation of both species.

Following this idea, we observed a general characteristic concerning the development of $\mathrm{P} 2$ in males of $M$. olfersi. The presence of males with the same size but with a great variation in the development of the P2 is a common situation in many of the specimens studied. For the past two decades, a combination of different tools, including morphological characterization of larvae, has helped to elucidate life histories, taxonomy and systematic of decapod crustaceans.

In the present revision of $M$. potiuna, we observed a great plasticity and the high intraspecific variability usually observed in Macrobrachium group. Then, the morphological results indicate/suggest that $M$. petronioi actually corresponds to an usual intraspecific variation in M. potiuna. In the same way, these morphological results also corroborated the great genetic similarity between both species (Pileggi \& Mantelatto, 2010) (Fig. 24). In addition, we recently performed a phylogeographic analysis on $M$. potiuna populations from all range of distribution, which corroborates this synonym proposal based on robust and with a very representative samples (CARVALHO et al., in press). In terms of larval morphology, we detected an intriguing scenario. MELO \& Brossi-Garcia (1999) in their larval description of $M$. petronioi mentioned the high similarity with larvae of $M$. potiuna. However, the former authors affirmed that certain characteristics of the larval morphology of $M$. petronioi enabled it to be distinguished from $M$. potiuna. In our opinion, some non-exclusive hypotheses may explain this apparent contradiction: differences detected in the morphology of maxillipeds (setae morphology, protopod and the epipod development) and uropods (suture in the exopod) between both species can be originated from (a) different accuracy and optical material during the analysis, (b) normal variation of these characters along the development (see comments of both topics in PoHLe et al., 1999), and finally (c) the possibility of misidentification of the species named as
M. potiuna. Thus, the possibility remains that there are no actual morphological differences between the zoea of $M$. potiuna and $M$. petronioi.

Our findings confirm that some species in Macrobrachium present a difficult systematic, either by morphology or by genetic structure, as well described in the literature. According to the taxonomic revision, we can conclude that the commonly used characters (shape, length and dentition of the rostrum; spines of the telson; morphology of P2) are not sufficient to solve many of the problems regarding the separation of the species. Actually, these characters are not maintained during the different stages of the animal development and between the sexes, what creates a great difficulty in delimiting the species. Therefore, the systematics of the genus Macrobrachium became greatly dependent on the interpretation of morphological characters and the combination of different tools. In the same way, molecular data showed that the few morphological differences used to separate the species are not consistent and the great intraspecific variability is common in Macrobrachium species (Pileggi \& Mantelatto, 2010). Finally, our investigation, based upon the complete review of the morphology, convincingly supported the idea of considering $M$. birai and $M$. holthuisi as junior synonymous of $M$. olfersi and in the same way $M$. petronioi as junior synonymous of $M$. potiuna. Therefore, 17 valid species of Macrobrachium are now reported in Brazil.

Acknowledgements. This study was part of the doctoral thesis of LGP and was supported by a fellowship from the Fundação de Amparo à Pesquisa do Estado de São Paulo - FAPESP (2005/50651-1) and ongoing Post-Doctoral fellowship CAPES (02630/2009-5). Additional support to this project was provided by FAPESP (Grants 2002/08178 9, Temático Biota 2010/50188-8; Coleções Científicas 2009/549310 ) and CNPq (Research Grants 472746/2004-9, 491490/2004-6, 473050/2007-2, and 471011/2011-8; Research Scholarships PQ $301261 / 2004-0$ and 302748/2010-5) to FLM. We are deeply grateful to many colleagues and friends (Alexandre Almeida, Célio Magalhães, Cassiano Calluf, Charles Fransen, Dib Ammar, Emerson Mossolin, Fabrício Carvalho, Georgina Bond-Buckup, Harry Boos Jr., Jeferson Nagata, Juan Bolaños, Marcos Tavares, Oliver Coleman, Sérgio Althoff) for their help in the first discussions, collecting, making available some essential fresh specimens and lending the materials from the collections used in our analysis. The support and assistance of the Postgraduate Program in Comparative Biology of FFCLRP/ USP during fieldwork and Julia Hetem for revision of the English text are gratefully acknowledged. Thanks go to anonymous reviewers for valuable comments on an earlier version of this manuscript. The collections of species conducted in this study complied with current applicable state and federal laws of Brazil (DIFAP/IBAMA 126/05; permanent license to FLM for collection of Zoological Material No. 11777-1 MMA/IBAMA/SISBIO).

\section{REFERENCES}

Abele, L. G. \& Kim, W. 1989. The decapod crustaceans of the Panama Canal. Smithsonian Contributions to Zoology 482:1-50.

Almaraz, G. A. R. \& Martínez, R. M. 2008. Conocimiento de los acociles y langostinos del noreste de México: Amenazas y propuestas de conservación, p. 167-206. In: Alvarez, F. \& Almaraz, G.A.R. eds. Crustáceos de México: Estado Actual de su Conocimiento. Nuevo León: Universidad Autónoma de Nuevo León. 
Bowles, D. E.; AzIz, K. \& Knight, C. L. 2000. Macrobrachium (Decapoda: Caridea: Palaemonidae) in the contiguous United States: A review of the species and an assessment of threats to their survival. Journal of Crustacean Biology 20(1):158-171.

Carvalho, F. L.; Pileggi, L. G. \& Mantelatto, F. L. In press. Molecular data raise the possibility of cryptic species in the Brazilian endemic prawn Macrobrachium potiuna (Decapoda, Palaemonidae). Latin American Journal of Aquatic Sciences.

De Grave, S. \& Fransen, C. H. J. M. 2011. Carideorum catalogus: the recent species of the dendrobranchiate, stenopodidean, procarididean and caridean shrimps (Crustacea: Decapoda). Zoologische Mededelingen 89(5):195-589.

Dugger, D. M. \& Dobkin, S. 1975. A contribution to knowledge of the larval development of Macrobrachium olfersii (Wiegmann, 1836) (Decapoda, Palaemonidae). Crustaceana 29(1):1-30.

Fransen, C. H. J. M. \& De Grave, S. 2009. Evolution and radiation of shrimp-like decapods: an overview, p. 245-260. In: MARTIN, J. W.; Crandall, K. A. \& Felder, D. L. eds. Decapod Crustacean Phylogenetics. Boca Raton: CRC Press.

Genofre, G. C. \& LobÃo, V. L. 1978. Macrobrachium holthuisi sp. n. a new species of shrimp (Decapoda: Macrura). Crustaceana 35(3):18-21.

Holthuis, L. B. 1950. The Decapoda of the Siboga-Expedition. Part $X$. The Palaemonidae collected by the Siboga and Snellius expeditions with remarks on other species I. Subfamily Palaemonidae. Siboga Expeditie, Monographie. 268p.

1952. A general revision of the Palaemonidae (Crustacea, Decapoda, Natantia) of the Americas. II. The Subfamily Palaemonidae. Occasional Papers of the Allan Hancock Foundation 12:1-396.

Holthuis, L. B. \& Provenzano JR., A. 1970. New distribution records for species of Macrobrachium with notes on the distribution of the genus in Florida (Decapoda, Palaemonidae). Crustaceana 19(2):211-213.

JAYACHANDRAN, K. V. 2001. Biogeography of palaemonid prawns of the world, p. 393-402. In: Jayachandran, K. V. ed. Palaemonid Prawns: Biodiversity, Taxonomy, Biology and Management. New Hampshire, USA: Science Publishers, Inc.

Kuris, A. M.; RA'anan, Z.; SAGI, A. \& Cohen, D. 1987. Morphotypic differentiation of male Malaysian giant prawns, Macrobrachium rosenbergii. Journal of Crustacean Biology 7(2):219-237.

Lobão, V. L.; Melo, G. A. S. \& Fernandes, W. 1986. Descrição de uma nova espécie do gênero Macrobrachium (Crustacea: Decapoda: Palaemonidae) da região sul de São Paulo. In: Congresso Brasileiro de Zoologia 13. Resumos. Cuiabá, Universidade Federal de Mato Grosso. p. 50.

Mantelatto, F. L.; Pileggi, L. G.; Suárez, H. \& Magalhães, C. 2008. First record and extension of the known distribution of the inland prawn, Macrobrachium aracamuni Rodríguez, 1982 (Decapoda, Palaemonidae) in Brazil. Crustaceana 81(2):241-246.

Melo, G. A. S. 2003. Famílias Atyidae, Palaemonidae e Sergestidae, p. 289415. In: Melo, G. A. S. ed. Manual de identificação dos Crustacea Decapoda de água doce do Brasil. São Paulo, Editora Loyola.

Melo, G. A. S.; Lobão, V. L. \& Fernandes, W. 1986. Macrobrachium petronioi sp. n. (Crustacea: Decapoda: Palaemonidae), uma nova espécie de camarão de água doce da região de Cananéia, SP. In: Congresso Brasileiro de Zoologia 13, Cuiabá, Resumos. Cuiabá. Universidade Federal de Mato Grosso. p. 51
Melo, G. A. S.; Lobão V. L. \& Fernandes, W. 1988. Redescrição de Macrobrachium birai Lobão, Melo \& Fernandes e Macrobrachium petronioi Melo, Lobão e Fernandes (Crustacea: Decapoda), palaemonídeos da região sul de São Paulo, Brasil. Boletim do Instituto de Pesca 15(1):89-97.

Melo, S. G. \& Brossi-Garcia, A. L. 1999. Postembryonic development of Macrobrachium petronioi (Caridea, Palaemonidae) in laboratory. Journal of Crustacean Biology 19(3):622-642.

2005. Desenvolvimento larval de Macrobrachium birai Lobão, Melo \& Fernandes (Crustacea, Decapoda, Caridea, Palaemonidae) em laboratório. Revista Brasileira de Zoologia 22(1):131-152.

Moraes-Riodades, P. M. C. \& Valenti, W. C. 2004. Morphotypes in male Amazon river prawns, Macrobrachium amazonicum. Aquaculture 236:297-307.

Mossolin, E. C. \& Bueno, S. L. S. 2003. Relative growth of the second pereiopod in Macrobrachium olfersi (Wiegmann, 1836) (Decapoda, Palaemonidae). Crustaceana 76(3):363-376.

Müller, F. 1880. Palaemon potiuna. Ein Beispiel abgekurzter Verwandbung. Zoologischer Anzeiger 3:152-157.

Ostrovski, M. C.; Fonseca, K. M. L. \& Silva-Ferreira, T. C. G. 1996. Macrobrachium denticulatum sp. $\mathrm{n}$. a new species of shrimp from the São Francisco basin, northeastern Brazil (Decapoda, Palaemonidae). Crustaceana 69(3):359-367.

Pereira, G. 1986. Freshwater shrimps from Venezuela I: Seven new species of Palaemoninae (Crustacea: Decapoda: Palaemonidae) Proceedings of Biological Society of Washington 69(2):198213.

. 1993. A description of a new species of Macrobrachium from Peru, and distributional records for Macrobrachium brasiliense (Heller) (Crustacea: Decapoda: Palaemonidae). Proceedings of Biological Society of Washington 106(2):339-345.

Pileggi, L. G. \& Mantelatto, F. L. 2010. Molecular phylogeny of the freshwater prawn genus Macrobrachium (Decapoda, Palaemonidae), with emphasis on the relationships among selected American species. Invertebrate Systematics 24(2):194-208.

Pohle, G. W.; Mantelatto, F. L.; Negreiros-Fransozo, M. L. \& Fransozo, A. 1999. Larval Decapoda (Brachyura), p. 1281-1351. In: Boltovsкoy, D. ed. South Atlantic Zooplankton. Leiden, Backhuys Publishers, vol. 2.

Ramos-Porto, M. \& Coelho, P. A. 1998. Malacostraca-EucaridaCaridea (Alpheoidea excluded), p. 325-350. In: Young, P. S. ed. Catalogue of Crustacea of Brazil. Rio de Janeiro, Museu Nacional.

Villalobos, A. F. 1969. Problemas de especiación en América de un grupo de Palaemonidae del genero Macrobrachium. FAO Fisheries Report 57(3):1055-1066.

Wiegmann, A. F. 1836. Beschreibung einiger neuen Crustaceen des Berliner Museums aus Mexico und Brasilien. Archiv für Naturgeschichte 2:145-151.

Wortham, J. L. \& VAn Maurik, L. N. 2012. Morphology and morphotypes of the hawaiian river shrimp, Macrobrachium grandimanus. Journal of Crustacean Biology 32(4):545556.

Wowor, D.; Muthu, V.; Meier, R.; Balke, M.; Cai, Y. \& NG, P. K. L. 2009. Evolution of life history traits in Asian freshwater prawns of the genus Macrobrachium (Crustacea: Decapoda: Palaemonidae) based on multilocus molecular phylogenetic analysis. Molecular Phylogenetics \& Evolution 52:340-350. 